\title{
Managing the innovative development of the food industry
}

\author{
Ludmila Kilimova ${ }^{1}$, Michael Cherkashin ${ }^{1}$, Alexey Pykhtin ${ }^{1}$, Tatyana Kolmykova ${ }^{1}$ \\ ${ }^{1}$ Southwest State University, 305040, Kursk, 50 Let Oktyabrya Street, 94
}

\begin{abstract}
The present paper concerns the theoretical and methodological foundations and development of recommended practices for managing the innovative development of food industry business entities. The analysis of scientific and methodological approaches to the management of innovation activities and their possible application to the management of innovative development of food industry enterprises has been carried out. Management of business entities innovative development has been considered as a set of processes and activities of the management cycle, forms and methods of its organization, aimed at ensuring the innovative development of business entities, achieving the stated mission and innovative goals using a targeted impact on the components of the innovation potential. The key problems of innovative development of food industry enterprises have been identified. The article summarizes the dayto-day realities and defines the prospects for innovative development of food industry enterprises amid the pandemic.
\end{abstract}

Keywords: food industry, food industry enterprises, innovation, innovation activities, innovation policy, innovative development, management of innovative development.

\section{Introduction}

Experts note that innovative transformations are a driver of growth in the efficiency of enterprises in any field of activity [18]. It is especially important to ensure investment transformations for enterprises in the agrarian sector and the food industry. The orientation of the food industry towards innovative development is an urgent and priority task for Russia.

The food industry is one of the branches of consumer goods industry that is an integral part of the agroindustrial complex, and is intended to meet the most critical human needs. This is an important, multiproduct, socially oriented sector of the national economy which ensures the production of a wide range of highquality consumer goods, contributes to the employment of the working-age population and improves its health and well-being. The result of its activities is the production of ready-to-eat food products together with semi-finished food products, beverages, as well as tobacco products, detergents and animal feed.

In terms of the product consumption level, this industry is far ahead of the markets of other goods. It unites thousands of enterprises, produces a fifth of the national product. Its main task is to process raw materials, supply high-quality products to the population, constantly providing the diet with proteins, fats, carbohydrates, vitamins and micronutrients. In fact, human life itself and the possibility of any kind of activity depend entirely on the normal functioning of one of the most important branch of industry. This area of production ensures the national food security, which is of crucial socio-political importance for the existence of the state itself. In addition, the food industry is closely connected with many related industries; it contributes to the development of agriculture, chemical and machinebuilding industries.

The efficiency of the food industry technological potential is determined by:

- $\quad$ supplies of agricultural products;

- the presence of facilities built;

- provision of all types of energy resources;

- efficient operation of transport.

Innovation is considered one of the key elements of enterprise success. In recent years, they have begun to play an important role in the food industry, which has generally been defined as a fairly mature and slowly developing sector [13].

The economic position of the industrial sector in Russia in recent years has been extremely ambiguous. On the one hand, there is a certain breakthrough in ensuring the growth of this sector of the national economy, during its transition to a more efficient development model.

On the other hand, Russian producers are forced to act against the backdrop of strong pressure from a number of external conditions and restrictions caused by the sanctions. An important obstacle hindering the development of the industrial sector is the insufficient level of competitiveness of domestic products in the world market. In this situation, the key factor in increasing the efficiency of the industry and the competitiveness of food products in the domestic and foreign markets is the activation of innovative activities of enterprises. Therefore, a special attention is paid to its development, treating the innovation activities of the food industry as a priority and providing significant state 
support. This is an urgent problem of innovative development of food enterprises.

\section{Research methods}

The methodological basis of the research conducted were the methods, principles and means of scientific knowledge, the use of which allowed us to ensure the reliability of the results. The paper uses a systematic approach, according to which all the processes and phenomena of managing the innovative development of the food industry were analyzed in interdependence. Owing to the application of this approach, the dependence of innovation activities development on economic transformations and globalization processes in the world economic system has been established.

To achieve the research goal and solve certain tasks, the following methods have been used in the paper: monographic - when studying the world experience in managing innovation activities in various countries; abstract-logical - to establish cause-and-effect relationships and form conclusions and suggestions; economic-statistical - to analyze the current state and trends in the development of the innovative potential of food industry enterprises in Russian regions; analysis and synthesis methods, computational and constructive when evaluating the effectiveness of the economic mechanism for managing the innovative development of food industry enterprises and to substantiate the directions for improving innovation activities; comparative analysis - when studying more in detail the methodological approaches, concepts, developments and suggestions proposed by leading domestic and foreign scientists on the peculiarities of managing the innovation activities of food industry enterprises.

\section{Results and discussion}

Management decision-making requires the search for the best actions and measures, and the latter ones are often made difficult due to the emergence of contradictions between traditional and innovative methods, the techniques of conducting activities by business entities. Such a transition from a traditional to a new type of activity occurs gradually, in stages, requires assessment, accumulation of new potential, search for effective ways to implement actions.

However, the path of innovative development is almost the only opportunity that allows business entities to occupy a worthy place in the domestic and world markets. Innovation activities are based on various innovative solutions, a number of which have the basis and status of a purposeful and continuous process. In this case, innovations are an opportunity to preserve sustainability and an impetus to reproduction. Innovative activities, as well as innovative development, perform an intermediary role for the transition from one state (the old one) to a qualitatively new state and, in comparison with traditional activities, is based on other values, requires new competencies, skills and abilities, aimed at other consumers. All this depends on the age and size of a business, its position in the market, existing and projected competencies, the pace of breakthrough, the nature and content of activities, etc.

The food market is highly competitive, since a significant number of domestic food industry business entities operate in this market. In addition, despite the sanctions, a considerable part of the total structure of Russia's imports of goods is still the share of imported food products, which creates additional competition for domestic food business entities.

Therefore, there arises a need to improve the innovation strategy of food industry business entities through their innovative potential strengthening, applying new management methods and research. Innovative development of food industry enterprises takes place, as a rule, through the development of various innovations. The latter may concern all spheres of business entities' activities. It should be noted that any sufficiently serious innovations in one area of an enterprise's activity, as a rule, require immediate changes in adjacent areas, and sometimes a general restructuring of organizational management structures [11].

Scientific research shows that innovation is the key to the successful development of a food industry enterprise, which is the motive for its implementation. Even if an enterprise constantly modernizes its products, the markets where the manufacturer works, they can enter a stage of decline, and enterprises that strive for development have to capture new opportunities from time to time. In addition, innovations are crucial for maintaining or increasing the level of profitability, which also acts as a motive in the economic mechanism for managing the innovative development of food industry enterprises. Under the pressure of competition, profitability indicators begin to decline quite quickly after the goods enter the market. The modernization of products and the expansion of specialization allows, at best, maintaining the level of profit, and only truly innovative products bring real significant income [17].

Innovation can include creating or reorganizing products or services to meet market demand, introducing new processes to improve productivity, developing or applying new marketing techniques and new forms of management systems to improve operational efficiency. According to Damanpour and Schneider (2009), pressures can be drive innovation from the external environment, especially competitiveness, deregulation, resource scarcity, and consumer demand. For these reasons, businesses change their behavior and organization to maintain or improve their performance and remain competitive in the marketplace.

Understanding innovation as a process is very important because it determines how we manage it [13]. Therefore, a significant part of business entities react rather slowly and without much effort to the competitors' actions. Nevertheless, only a small part of them are searching for radically new innovative directions and solutions. Having this in mind, business managers can work out their own moves more carefully and choose such solutions, owing to which their enterprises will increase their competitiveness and gain a 
competitive advantage. However, the innovative development of industry, including food industry enterprises, is very difficult without active state participation. The main reasons for this are the following interrelated circumstances:

- science-intensive products satisfy mainly public, rather than individual needs [15].

- a relatively high duration of the production cycle (putting forward an idea, fundamental, then applied research, single, serial, mass production);

- this is, as a rule, an expensive production: the amount of initial capital is not sufficient for a private entrepreneur, and often for individual joint-stock companies;

- mainly large-scale production is effective, and it is integrated both horizontally and vertically;

- innovations are aimed at achieving the strategic goals of the society (country), the attractiveness of which for private capital is not always obvious and is almost always excessive temporarily [6].

That is why the management of enterprises' innovative development is carried out within the existing restrictions. Based on this, there is a need to identify the institutional foundations of innovation, that is, the role of the state in creating conditions for innovative development [Воробьева, 2015; Морозов, 2010].

This requires the state's governing apparatus to form and implement an innovation policy, within the framework of which the directions and rates of innovative development of meso - and microeconomic levels are determined at the state level. The internal environment of the country is determined by the innovative potential of economic entities, the level of this potential management.

The performance of the innovation potential management process makes it possible to ensure not only uninterrupted technology improvement, the production of innovative and competitive products, but also to achieve continuous, sustainable innovative development, economic growth, and strategic stability of production.

The state's stimulating policy in the innovation sphere should be implemented in a comprehensive manner: on the one hand, it should create a favorable investment climate for innovative programs implementation; on the other hand, it should introduce special incentives for technological innovative changes at the state level.

Innovation policy in the economically developed countries of the world differs only in the degree of state intervention, the level of scientific and technological progress and the needs of the society of a certain country [16]. Therefore, the nature of cooperation between science and government is extremely important in the issue of stimulating innovation activities, since only the creation of an effective mechanism for interaction between scientific institutions and government structures can help in the implementation of state innovation policy, and, consequently, in the dynamic development of innovation activities.

An interesting aspect, in this regard, arose in Spain and concerns public funding: food companies that received national funds and invested in $R \& D$ almost
54\% more than companies without government support. In addition, it was noted that R\&D expenditures for product and organizational innovations are more relevant than those invested in process innovations (Alarcon, Arias, 2018).

At the present stage of innovative development of Russia's food industry economic entities, it is worth mentioning the following methods of stimulation at the state level:

- creating an innovative climate;

- implementation of innovations adaptation mechanism;

- formation of innovative social technologies;

- planning, forecasting and modeling of innovations;

- ensuring communicative interaction in innovative processes.

In order for the development of innovations and the strengthening of the economy, it is necessary that the state in every possible way contribute to this, developing education, science and financing science-intensive industries and production.

To date, out of the total amount of funding for various types of innovations, the distribution structure is as follows[5]:

- about $67 \%$ of funds are spent on various developments;

- up to $18 \%$ for applied research;

- up to $15 \%$ for basic research.

At this stage, all innovations that exist in the country have:

- either internal developments;

- either brought in as imports. Here the costs correspond to approximately 3305 conventional units.

There is also a part that is exported. In this case, the budget receives 1181 conventional units.

As you can see, the state spends more on the acquisition of technologies than it has from their sale abroad. That is, Russia has a negative balance of payments for technology. In this regard, the Russian Federation is inferior to Great Britain, Germany, Italy, Canada, USA, France, Japan and a number of other developed and developing countries[5].

Organizations update products and processes almost equally: product innovations were implemented by twothirds $(67.3 \%)$ of organizations that had in 2017-2019. completed innovations; process rooms - $62.6 \%$.

Industrial enterprises rely more on updating products than on processes $(74.6 \%$ versus $58.3 \%$, respectively); in other sectors, process innovations prevail in the innovation portfolio[5].

The performance of innovations in Russia is below the expected level at the current values of the indicators of GDP per capita and investment in science, technology and innovation. Lagging behind the leading countries is traditionally determined by the low efficiency of institutions that create conditions for entrepreneurial and creative activity [4].

The implementation of fundamental documents of a forecast and program-target nature, including "Longterm forecast of scientific and technical development of agriculture and related industries for the period up to 
2030", "Strategy for the development of mechanical engineering for the food and processing industry of the Russian Federation for the period up to 2030" (hereinafter - the Strategy) will be of decisive importance for the transition of food industry enterprises to an innovative path of development [Крылатых Э. Н., 2015] The strategy defines the priorities, goals and tasks facing the discussed segment, as well as ways to achieve them effectively. The strategy is designed to create the necessary conditions for the industry modernization, the formation of an innovative technological structure, the solution of financial, economic and social problems, as well as to promote the implementation of the Russian Federation socio-economic development goals until 2036.

An important incentive for attracting investment in the food industry innovative development can be the simplification of tax conditions. Innovation activities in the process of taxation have their own specifics, because the person who finances innovations bears the greatest risk, since they may not be realized and may not bring profit. Therefore, tax incentives should be focused primarily on various investors.

Innovations in the food sector represent the implementation of the developments and research results in the form of new improved food products, new technologies, new forms of organization and management, new approaches to the management of human resources and the formation of social services in economic practice. With the existing variety of classification approaches for industrial complex enterprises, product, technological, organizational, marketing and environmental types of innovations should be distinguished from the total volume of innovations [3].

Product innovations of the food industry - a product that has a novelty, obtained as a result of innovation activities, intended for mass consumption, for certain categories of persons and groups of the population with the aim of: expanding the range and nomenclature, treatment and prevention, meeting the needs of the population in the consumption of food products other than traditional ones.

Technological or process innovations are designed to facilitate, improve the process of obtaining innovation through the use of new technologies, improving the technological process.

Marketing innovations are aimed at market research, new sales channels, finding new consumers, using new sales techniques, advertising innovative products, promoting food products to sales markets, forming new price strategies.

Organizational innovations are a new method of running a food facility, organizing new external relations, organizing workplaces, a new management style, making new creative decisions.

Environmental innovations cover innovations related to various methods of improving the environmental situation in the food sector.

To ensure the competitiveness of food industry enterprises, to increase the efficiency of their activities, it is necessary to introduce an economic mechanism for managing innovative development. Any innovative development is not only the main innovation process, but also the development of a system of factors and conditions necessary for its implementation, that is, innovative potential. Therefore, in order to develop an economic mechanism for the innovative development of enterprises, we consider it expedient to formulate a general concept for managing the innovative development of an enterprise, taking into account the needs of social development and restrictions associated with the use of all available resources.

In its most general form, the concept of managing the innovative development of food industry enterprises, in our opinion, should contain: management principles; criteria for selecting priority areas of innovative development; priorities for innovative development; stimulating innovative development, which includes forms, methods and tools for managing innovative development. We also believe that restrictions should take into account not only those related to the use of available resources, but also the organizational and legal support of innovative development.

Thus, innovations and competent management of the innovation process will allow us to modernize and diversify production in the food industry, increase the competitiveness of food products and expand their sales market, create favorable institutional conditions for the development of the industry, coordinate the training of scientific personnel and specialists in this industry, carry out their training and retraining, develop and apply intensive technologies for the production of food products, ensure the integration and cooperation of industries and productions.

\section{Conclusion}

In the food industry, new technologies are primarily aimed at reducing and eliminating "the bacterial load":

- electric heated auger for bulk materials;

- microwave thermal sterilization of meat and seafood;

- vacuum displacement of moisture under the influence of microwaves;

- processing of packaged products with high pressure;

- changing the quality of food under the influence of a pulsed electric field;

- improvement of the technological process through the introduction of automation and robotization elements.

In addition, with the introduction of innovations, the very principles of manufacturing and storage of products are changing. The quantity and quality of ingredients used in the production process is significantly increasing. Enzymes, microbes, dietary fibers, synthetic additives are being more actively used.

Management of the innovation process in the food industry involves:

- conducting research and development, providing deep processing of raw materials and obtaining innovative food products; 
- development of modern resource-saving methods and technologies in food production;

- development of highly effective technologies for safe general, special and baby food products;

- development of technologies for functional food products with a metabolically adequate composition that contribute to improving the effectiveness of pathologies treatment;

- development of scientific foundation and production methods for greening the food industry in order to reduce the anthropogenic impact on the environment through the development of scientifically based recommendations, methods and technical solutions for greening industrial technologies that increase the level of complexity of processing raw materials and environmental protection.

In order to ensure the long-term progressive development of food industry enterprises under presentday conditions, it seems appropriate to substantiate and implement comprehensive anti-crisis programs related to the modernization of both production activities, assortment policy, and the introduction of new approaches to financial and labor management of industry enterprises.

Innovative potential management is effective if this process allows business entities to maintain a stable competitive position in the market, which is due to the formation and maximum use of innovative potential.

The functions and guidelines for the management activities of state bodies in the direction of the development of innovations in the food industry should be: development of types of economic activities that are at the global level to enhance the innovation process and stimulate the development of the food industry; increasing the number of innovative projects and strengthening international cooperation; development of an innovative strategy focused on increasing the competitiveness of food industry enterprises in the context of globalization; the formation and promotion of innovative clusters, in which food industry business entities will take an active part; development of the transfer of technologies that are necessary for the functioning of business entities in the food industry; renewal of infrastructure in the innovation sphere.

The publication was carried out within the framework of the state assignment for 2020 No. 0851 2020-0034

\section{References:}

1. E.N. Krylatykh et al. Agrarian Europe in the XXI century ("Summer Garden", Moscow, 2015)

2. I.M. Vorobyeva Young Sci-t Institutional foundations of innovation management 10 (90) 574 (2015)

3. A.A. Zyablov Econ.: yd, today, tomorrow Innovative development of the Russian food industry: opportunities and limitations 2136 (2016)
4. L.M. Gokhberg, K.A. Ditkovsky, E.I. Evnevich, etc. Indicators of innovation activity: 2020: statistical collection (HSE, Moscow, 2020)

5. L. M. Gokhberg, G. A. Gracheva, K. A. Ditkovsky, etc. Indicators of innovation activity: 2021: statistical collection (HSE, Moscow, 2021)

6. E.M. Korostyshevskaya, T.P. Nikolaeva Bull. of St. Petersburg Univ. The innovative potential of Russia and the conditions of its development 5134 (2007)

7. D.I. Morozov Modern trends in econ. and manag.: a new view Institutional foundations of innovative enterprise development 4-1 (2010)

8. O.O. Nishnianidze, M.D. Cherkashin, D.S. Bogdanova Bull. of the SWSU Ser.: Econ.. Soc. Manag. Social health as a socio-cultural phenomenon 9 5(34) 1972019

9. S.Rakhimova Int. J of Innovative Tech.s in Econ. The role of innovation and the innovation process in the development of the food industry 2 6(18) 15 (2018)

10. K.S. Fioktistov Probl. of econ. and manag. Problems of the development of the Russian food industry in the context of the coronavirus pandemic 834 (2020)

11. M.V. Shaburishvili Condit. for improve. the effic. of the Rus. Econ.: coll. of sci. work Innovation activity as the implementation of the innovation process on the scale of the organization (2020)

12. S. Alarcón, P. Arias Spanish J. Agric. Res. The public funding of innovation in agri-food businesses 16(13) 164 (2018)

13. B. Bigliardi, G. Ferraro, S. Filippelli, F. Galati Innovation Models in Food Industry: A Review of The Literature // J of Tech. Manag. \& Innov. 153 (Santiago, 2020)

14. F. Damanpour, M. Schneider Characteristics of innovation and innovation adoption in public organizations: assessing the role of managers $\mathrm{J}$ of Public Admin. Res. and Theory 19(3) 495 (2009)

15. L. Kilimova, O. Lysikova Health as a fundamental basis of population life quality // Ekonom. chasopisXXI 11-12 191 (2019)

16. R. Hassink, R. Rutten, F. Boekema The learning region: a constructive critique / // The Learn. Reg.: Found., St. of the Art, Future 252 (Edward Elgar, 2007)

17. F. Moulaert, F. Sekia Reg. Stud. Territorial Innovation Models: A Critical Survey 372892003

18. A.S. Obukhova, T.S. Kolmykova, S.V. Klykova P.N. Mashegov, A.G. Zaitsev, O.V. Popova E3S Web of Conf. Efficient Prod. and Proc. ICEPP-2021 Features and benefits of digital technologies in agricultural enterprises 24701018 (2021)

19. A. Sakhno, I. Salkova, A. Broyaka, N. Priamukhina Int. J of Recent Techn. and Eng. (IJRTE) Methodology for the Impact Assessment of the Digital Economy on Agriculture Development 8160 (2019) 
20. G.V. Fedotova, I.F. Gorlov, A.V. Glushchenko, M.I. Slozhenkina, A.K. Natyrov Dig. Econ.: Compl. and Variety vs. Rationality. ISC 2019 Trends of
Scientific and Technical Development of Agriculture in Russia 87 (2020) 